Abstracta Iranica

Revue bibliographique pour le domaine irano-aryen

Volume 34-35-36 | 2017

Comptes rendus des publications de 2011-2013

\title{
David Durand-Guédy. Ruling from the outside. A new perspective on early Turkish kingship in Iran
}

\section{Jürgen Paul}

\section{OpenEdition}

1 Journals

\section{Electronic version}

URL: http://journals.openedition.org/abstractairanica/41820

DOI: 10.4000/abstractairanica.41820

ISSN: 1961-960X

Publisher:

CNRS (UMR 7528 Mondes iraniens et indiens), Éditions de l'IFRI

\section{Electronic reference}

Jürgen Paul, « David Durand-Guédy. Ruling from the outside. A new perspective on early Turkish kingship in Iran », Abstracta Iranica [Online], Volume 34-35-36 | 2017, document 6, Online since 30 December 2016, connection on 26 September 2020. URL : http://journals.openedition.org/abstractairanica/ 41820 ; DOI : https://doi.org/10.4000/abstractairanica.41820

This text was automatically generated on 26 September 2020.

Tous droits réservés 


\title{
David Durand-Guédy. Ruling from the outside. A new perspective on early Turkish kingship in Iran
}

\author{
Jürgen Paul
}

\section{REFERENCES}

David Durand-Guédy. « Ruling from the outside. A new perspective on early Turkish kingship in Iran ", in : L. Mitchell and C. Melville, eds., Every Inch a King. Comparative Studies on Kings and Kingship in the Ancient and Medieval Worlds. Leiden, Brill, 2012, p. 325-342.

1 The following three texts are the outcome of a research project termed "Ruling from the Outside. Turkish Lords and City-Life in Pre-Mongol Iran" which Durand-Guédy has conducted in different contexts (in France, Iran, Japan, and Germany) (see introductory note on page 325). It started from a seemingly very simple, but in fact very complex question which also was chosen as a title for the second text: Where did the Seljuqs live? This means that the project aimed at bringing the spatial component in, the localisation of power (spatialisation du pouvoir), considering first that power is not present in equal density in every spatial context, and that it can be projected into space in various ways; another starting point is the reflexion that rulers relate differently to the space(s) over which they claim control.

2 In the entire project, Durand-Guédy tackled the accepted wisdom that the Seljuqs differed from the Mongols (or rather, that the Mongols were different...) in many ways. The Seljuqs, to distinguish them from the Mongols, continued the existing IranianIslamic political culture - albeit with some changes. This included that they settled down, literally, and lived in palaces whereas their ancestors, and also the conquerors themselves, had lived in tents. 
3 Durand-Guédy checks this assumption on three levels; these three levels are also distinguished in the next two papers. The first level concerns territory. Was the ruler fixed in space or was he mobile? The second level is about the urban space: was the court within or without the city walls, and what does that tell us about the sultan's relationship to the cities in his realm? And the third level is the habitat itself: a palace or a tent, and what in between?

4 Durand-Guédy then shows, in particular for the 12th century, that in all respects, the urban and sedentary nature of Seljuq rule has to be reassessed. The sultans were mobile (but this does not mean that their mobility followed nomad patterns), the court was not in the city, but in the royal encampment, and the sultans lived in tents, not in palaces. Structures in between include the royal pavilion ( $k \bar{u} \bar{s} k)$, a comparatively light structure designed for watching games of polo and military parades. Therefore, the conclusion is that there was a deep divide between rulers and the ruled (urban, sedentary, Iranian) population. But this made the strength of the $a^{\prime} y \bar{a} n$ families such as the Hujandīs: "Seen from the cities, Saljuq kingship was low-key and unobtrusive, and what the Iranian elite lost in pomp, they gained in autonomy" (338).

\section{AUTHORS}

JÜRGEN PAUL

Université de Hall 